\title{
RURAL DEVELOPMENT IN THE EUROPEAN UNION THROUGH TOURISM POTENTIAL
}

\author{
Liudmyla Maliuta', Nataliya Harmatiy², Iryna Fedyshyn ${ }^{3}$, Uliana Tkach ${ }^{4}$ \\ ${ }^{I}$ Doctor of Economics, Professor, Ternopil Ivan Puluj National Technical University, Ternopil, Ukraine, Phone No.: \\ +38-067-170-00-20, E-mail address: luda_mal@ukr.net, ORCID ID: 0000-0002-7569-9982 \\ ${ }^{2}$ PhD in Economics, Associate Professor, Ternopil Ivan Puluj National Technical University, Ternopil, Ukraine, Phone \\ No.: +38-067-735-45-54, E-mail address: garmatiy.nat@meta.ua, ORCID ID: 0000-0003-4426-9223
}

${ }^{3}$ PhD in Economics, Associate Professor, Ternopil Ivan Puluj National Technical University, Ternopil, Ukraine, Phone No.: +38-063-644-05-71, E-mail address: ira.fedyshyn@gmail.com, ORCID ID: 0000-0001-5531-4566

${ }^{4}$ PhD in Economics, Associate Professor, West Ukrainian National University, Ternopil, Ukraine, Phone No.: +38-098 775-75-49, E-mail address: u.tkach@wunu.edu.ua, ORCID ID: 0000-0001-6201-1555

Received 2009 2021; Accepted 13102021

\begin{abstract}
The article analyses the impact of coronavirus COVID-19 on the rural territories` condition and shifts which faced the countryside's economy in conducting business. Using the tools of economic and mathematical modeling (based on correlation-regression), analysis of the impact of the indicator "market related expenditure and direct aids" (MREDA) on "rural development expenditure" (RDE) was made. The correlation between the indicator "financial framework total" (FFT) and MREDA was studied. It was found that tourism has a high potential to revitalize rural business and infrastructure the development of which were hardly hit by pandemic and suffer from the effects of crises caused by it. A structural scheme improving rural development by tourism promotion through financial and credit stimulation of tourist activity in rural areas was elaborated. It also details in blocks a tool for solving problems from the economic, legal, social and informational point of view.
\end{abstract}

Keywords: agricultural policy, economic damage, rural tourism, region, correlation-regression analysis, incentives. JEL Codes: Q13, R51, Z32.

\section{Introduction}

Rural areas face significant challenges connected with today's cascading risks, which are becoming real threats due to nonlinear processes. The impact of negative factors, which lasts more than 2-3 years, in fact, begins to generate influences that destroy the economic system, and thus affect the development of rural infrastructure (roads, water supply, flood prevention systems, irrigation pipes, etc.).

At many points, the economic performance of agriculture is declining (Fedyshyn I.B., Harmatiy N.M., 2020). The tool that can lead to the development of rural infrastructure and improve the economic opportunities of rural areas, in our opinion, is tourism, mostly internal or domestic one. The tourism experience of Europe, as the region with the highest tourism revenues, is extremely important. Travelers' desire for rural goods and services provides great opportunities to restore countryside.

Thus there is an obvious prospect in the growth of countryside infrastructure through the development of the tourism component. However, to date there is little research about

Copyright (C) 2021 Author(s), published by Vytautas Magnus University. This is an open access article distributed under the terms of the Creative Commons Attribution Non-Commercial 4.0 (CC BY-NC 4.0) license, which permits unrestricted use, distribution, and reproduction in any medium provided the original author and source are credited. The material cannot be used for commercial purposes. 
the size and perspectives of this segment. It is worth noting that in the XIX century the need for economic tourist information increased very rapidly due to the formation of tourism itself and its growing impact on the economies of the world. In the XXI century it has become a mass socio-cultural phenomenon, and therefore has led to the emergence of many developments of various scientists, practitioners and stakeholders in the field. Martín J.M.M. et al. (2018) reveal the pre-crisis problem of the mass of travelers during some periods and reveals that sometimes such state of affairs can have bad consequences on the area. The paper intends to analyze the worldwide common pressure on the destinations and environment. The conclusion was that there are some unfavorable effects on the economy of the touristic spot.

However, what happened to the world in 2020 due to the spread of coronavirus COVID-19 was not expected. When there was a need to develop new business models, to actively use digital technologies in order to stay afloat, rural business faced the problem of rapid adaptation of new management methods and the application of innovative high tech. One of the consequences of these changes was the need to analyze data, information, develop forecasts and new solutions to this issue. Many studies have been made to give some fundament for implication of better management solutions and reducing the economic damage.

Yes, in particular, Sigala M. (2020) in her study debates the terms when some threats can be an occasion for the business, the conditions and some issues caused by the pandemic.

In the article of Lithuanian authors Žilinskas V., Maksimenko M. (2008) a research of the state of village tourism in Lithuania is presented, a SWOT-analysis of rural tourism in Lithuania is proposed and prospects for its sustainable development are discussed. This work is also of interest because the authors analyzed rural tourism in Lithuania as one of the ways to make living conditions better.

The main task of the paper is to analyze and diagnose the effects of coronavirus on rural tourism business and develop solutions to improve the economy and infrastructure of rural areas by expanding the tourist space, which nourishes folk culture, traditional crafts and positively affects the economy of this area.

\section{Research results and discussion}

Researching the development of the agricultural sector of the European Union (EU), it should be considered that one of the important directions is the highlight of the development and implementation of methods and tools of managerial influence on the support and functioning of socioenvironmental responsibility of business entities, elements of which are the development of investment programs in rural areas. Cooperation with local communities and local authorities is extremely important for the development of the tourism component of business as a supporting link for agricultural development.

The financing of the European Union's rural economy in the 2019 was due to financial activities designed for 2014-2020. Rural development expenditure in rural areas in European Union for 2014-2020 are presented in table 1 (EAFRD, 2019). 
Management Theory and Studies for Rural Business and Infrastructure Development

eISSN 2345-0355. 2021. Vol. 43. No. 4: 555-561

Article DOI: https://doi.org/10.15544/mts.2021.50

Table 1. Rural development expenditure in rural areas in European Union for 2014-2020

\begin{tabular}{|l|c|c|c|c|c|c|c|}
\hline Year & $\mathbf{2 0 1 4}$ & $\mathbf{2 0 1 5}$ & $\mathbf{2 0 1 6}$ & $\mathbf{2 0 1 7}$ & $\mathbf{2 0 1 8}$ & $\mathbf{2 0 1 9}$ & $\mathbf{2 0 2 0}$ \\
\hline $\begin{array}{l}\text { Financial } \\
\text { framework } \\
\begin{array}{l}\text { total, million } \\
\text { EUR }\end{array}\end{array}$ & 49857 & 64692 & 64262 & 60191 & 60267 & 60344 & 60421 \\
\hline of which: & 5298.9 & 18183.7 & 18683.7 & 14371.2 & 14381.0 & 14690.6 & 14709.4 \\
\hline $\begin{array}{l}\text { - Rural } \\
\text { Development }\end{array}$ & 43778.1 & 44189.8 & 43950.2 & 44145.7 & 44162.4 & 43880.3 & 43887.1 \\
\hline $\begin{array}{l}\text { - Market related } \\
\text { expenditure and } \\
\text { direct aids }\end{array}$ & 4375 &
\end{tabular}

*Source: made by the authors on the basis of (EAFRD, 2019).

Considering the latest events in the world the statistics (Distribution of travel..., 2021) show that revenues from travel and tourism amounted $\$ 4.7$ trillion in 2020. The decline in the share of GDP in 2020 comparing to 2019 was $49.1 \%$. It is worth noting that the overall decline in GDP of the world economy in 2020 reached $3.7 \%$. The share of the tourism industry in the world's GDP in 2019 was $10.4 \%$, and in $2020-5.5 \%$. This occurred because of global restrictions on border crossings. In 2019, the number of all employed in the tourism industry was 334 million people, in 2020 there was a drop to 272 million people employed in this field. Thus there was reduction of 62 million jobs. Revenues from domestic tourist flows decreased by $45 \%$, and revenues from external and international tourist flows decreased by an unprecedented $69.4 \%$.

The total contribution of tourists to the GDP of Europe, which traveled within their own country in 2019, was $66 \%$. It is worth noting that in 2020 there was a tendency of increasing number of tourists traveling within their own country. This situation was caused by uncertainty and restrictions on crossborder movements. Thus, $73 \%$ of the total contribution of the tourism industry to Europe's GDP was generated by domestic travel spending (Distribution of travel..., 2021).

The tourist potential of rural areas in Spain is evidenced by the period of 20002019, whereas the number of international tourists in rural areas has steadily grown since 2009, and the number of domestic tourist flows has steadily grown since 2014. For example, in 20193.5 million domestic tourists and 900 thousand foreigners stopped in countryside areas in Spain. The total amount of domestic tourists staying in countryside accommodations was clearly higher than that of tourists from abroad (Yearly number..., 2021).

In the period of 2010-2019, there was an increase in the total number of agricultural and ecotourism objects in Italy. In 2010, they amounted 16.6 thousand, 20.3 thousand in 2018 , with a further decrease to 20.1 thousand in 2019 (Number of agritourism..., 2021).

The results of a survey conducted in the United Kingdom of Great Britain showed that $34 \%$ of respondents wanted to spend their summer holidays in any coastal city, and 30\% desired to spend their free time in rural areas. And only $12 \%$ of respondents were likely to spend their vacation in the mountains (Leading destinations..., 2021). It is also worth noting that statistics showed 358 million trips to rural areas in 2019 in the UK (Number of tourism..., 2021).

All these figures and trends in today's conditions of international tourism indicate in favor of rural development, since more and more travelers choose ecotourism, bringing additional income to rural areas.

Using the tools of economic and mathematical modeling (based on correlationregression), analysis of the impact of the 
indicator MREDA on RDE (table 1) was made. The calculations were performed in Excel - module "data analysis". The results of the simulation are presented in Fig. 1.

It was found that the coefficient of determination $\mathrm{D}^{2}=1$, which indicates the adequacy of the constructed model.
The correlation coefficient between indicators is $\mathrm{R}^{2}=1$, which indicates a $100 \%$ relationship between indicators MREDA and RDE. This means that with the increasing dynamics of market costs, rural development will improve by $100 \%$.

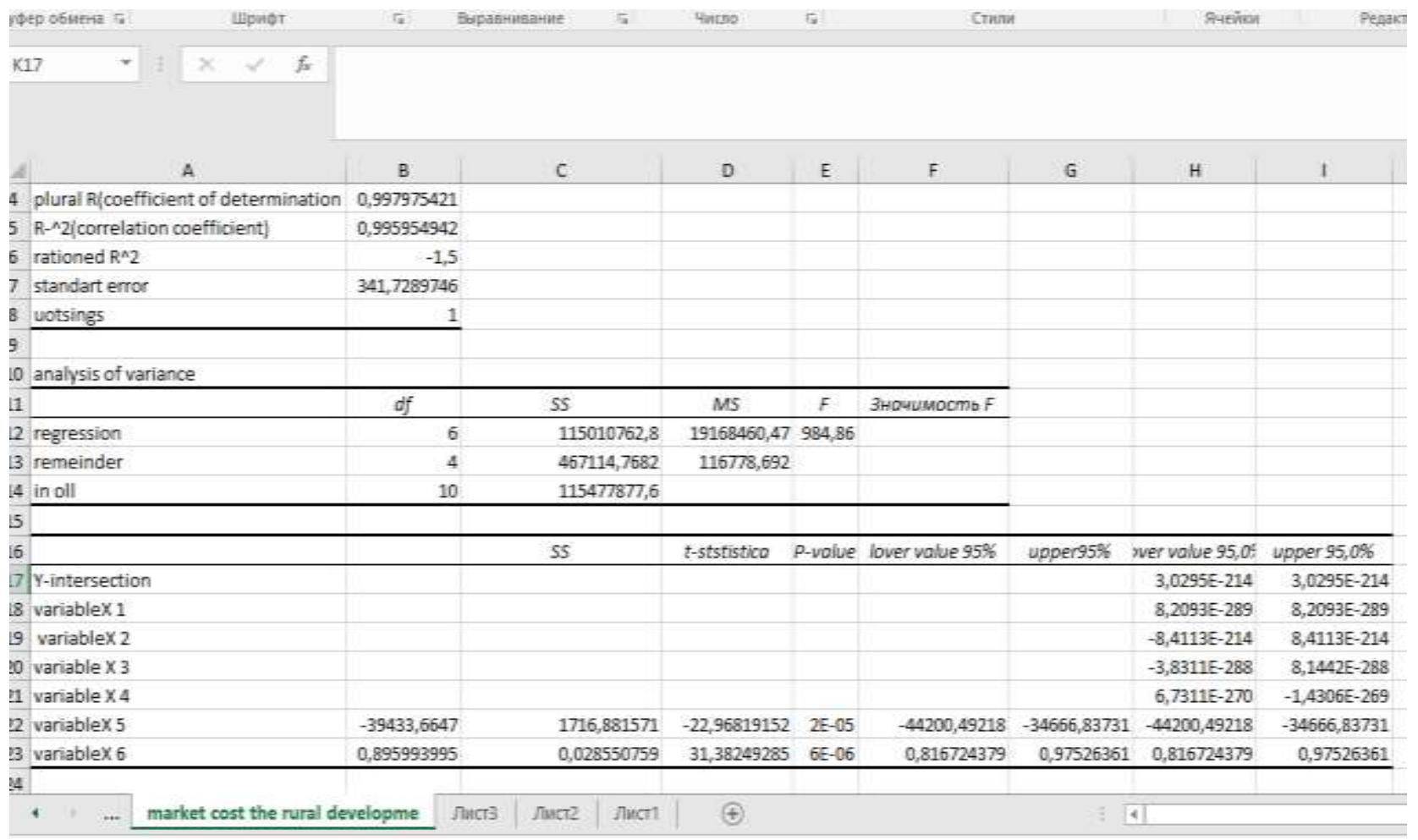

Figure 1. Results of the correlation-regression analysis of the impact of MREDA on RDE

The regression equation of the impact of the indicator MREDA on RDE has the form:

$$
y=-39433,7+0,9 x
$$

The calculation of the coefficient of elasticity will take the form:

$$
\begin{gathered}
y=\frac{a_{1} \bar{x}}{a_{0}+a_{1} \bar{x}} \\
y=\frac{0.9 * 44045,24}{-39433,7+(0.9 * 44045,24)}=191,49
\end{gathered}
$$

The calculations of the coefficient of elasticity show that with an increase in market related expenditure and direct aids by at least $1 \%$ rural development expenditure will increase in 191.49 times. This indicates a synergistic relationship between financial costs for the development of rural tourism, which allows to dynamically increase other areas of rural development.

The relationship between the dynamics of the indicator FFT and MREDA (table 1) was also studied. Correlation-regression analysis was used for this purpose.

The simulation revealed that the coefficient of determination is $\mathrm{R}^{2}=0.65$, which indicates the adequacy of the constructed model, and the possibility of further research and calculations. The correlation coefficient between indicators FFT and MREDA indicates the average density between indicators. A positive value of the correlation coefficient indicates a direct relationship between the indicators, that is, with increasing dynamics of the indicator FFT, the dynamics of MREDA will also increase. 
The equation of correlation-regression analysis between these indicators took the form:

$$
y=42776.92+0.021 x
$$

The coefficient of elasticity for these indicators according to formula (3) will be:

$$
y=\frac{0.021 * 43999.1}{42776.92+(0.021 * 43999.1)}=0.2
$$

The simulation indicates that if the total financial framework changes by at least $1 \%$, market related expenditure and direct aids will increase by $2 \%$.

Guided by the results of the study, a block schematic chart of improving a rural development through regional tourism development was elaborated (fig.2).

There are six basic blocks for improving rural development through tourism promotion. They include: financial and credit incentives for tourism in rural areas; tax incentives; international cooperation and interaction; attracting financial resources of the region`s households in eco-tourism; legal support of financing tourism development in rural areas; decision support at all stages of ensuring the development of tourism in rural areas in the field of digital technologies; promotion of tourism in rural areas and social awareness.

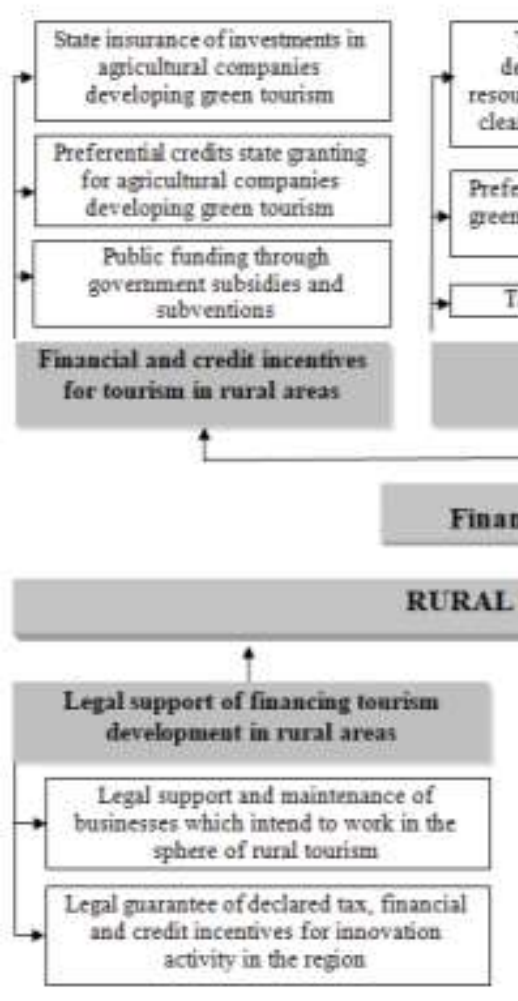

Tax exemption for the development of financial resources in geen tourism for a clearly defined period of time

Preferential taxes rates for the of green touriam firms operating in nural areas

Tax incentines

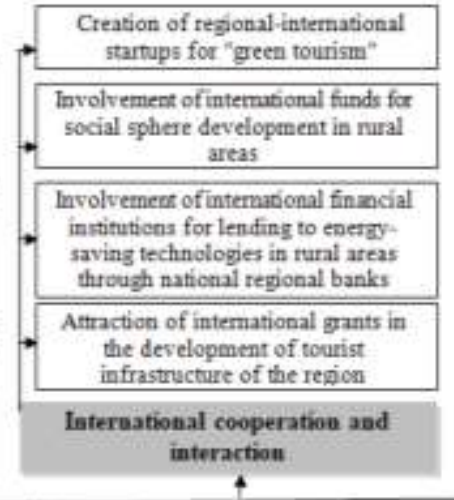
Creation of investment funds artached to municipal structures and territarial cammunities on the basis of financial capital
involvement of the commanity, for the development of tourist infrastructure in rural regions

Attracting firancial resources of the region's hoasebolds in ecotourim 4

Financial and credit stimulation of tourist activity in rural areas

URAL DEVELOPMENT THROUGH TOURISM PROMOTION 


\section{Conclusions}

The crisis caused by the spread of coronavirus COVID-19 has suddenly reached a large scale and affected both rural tourism business, forcing enterprises, those working in the tourism sphere, to adapt, applying new business models and approaches to management. Countries in which the process of social reproduction worked effectively under the influence of built-in regulators, which led to significant resistance to external and internal threats, were characterized by a high level of economic security (Germany, France, Japan, South Korea, China, etc.) did not avoid economic losses - the consequence of the total lockdown in 2020.

However, creating new opportunities for the introduction of new methods of business management in rural areas requires appropriate efforts, including the preservation of natural and historical heritage, the promotion of digital technologies, state support and investment. Advancing tourism in the countryside helps to use advantages of the industry, assures employment, provides additional income and satisfies the tastes of any tourist. Trips to the countryside can be a benefit for the development of the region`s agriculture and rural territory.

The calculations of the elasticity coefficient using the tools of economic and mathematical modeling (based on correlation and regression) showed that with increasing market related expenditure and direct aids at least of $1 \%$ rural development expenditure will increase 191.49 times.

The simulation of the relationship between the dynamics of the indicator FFT and MREDA indicates that if the total volume of the financial framework changes by at least $1 \%$, market related expenditure and direct aids will increase by $2 \%$.

A block schematic chart of improving rural development by tourism promotion was elaborated. It details in blocks a tool for solving problems from the profitable, legal, social, informational perspective. The proposed solutions will help to significantly improve the development of regional tourism.

\section{References}

Distribution of travel and tourism spending in Europe in 2019 and 2020, by type of tourist. Statista (2021). Retrieved from https://www.statista.com/statistics/617405/travel-tourism-contribution-europe-gdp-foreign-domestic/ [9.09.2021]

EAFRD (2019) 13th Financial report from the commission to the European parliament and the council on the European agricultural fund for rural development (EAFRD) 2019 financial year. Brussels, 20.8.2020 - 17 p.

Fedyshyn I.B., Harmatiy N.M. (2020). Investytsiino-innovatsiina diialnist pidpryiemstv promyslovosti Ukrainy [Investment and innovation activity of industrial enterprises of Ukraine]. Halytskyi ekonomichnyi visnyk, TNTU Galician Economic Bulletin, TIPNTU. Issue 63,№2, 26-34 pp.

Yearly number of tourists staying in rural accommodations in Spain between 2009 and 2019 (in 1,000s). Statista (2021). Retrieved from https://www.statista.com/statistics/765361/annual-number-of-tourists-in-rural-accommodationsin-spain/\#statisticContainer [5.08.2021]

Leading destinations for travelers' next summer staycation in the United Kingdom as of March 2021. Statista (2021). Retrieved from https://www.statista.com/statistics/1228976/summer-staycation-destinations-uk/ [6.05.2021]

Martín J.M.M. et al. (2018). Effects of Vacation Rental Websites on the Concentration of Tourists-Potential Environmental Impacts. An Application to the Balearic Islands in Spain. Int J Environ Res Public Health. 15(2):347. doi: 10.3390/ijerph15020347

Number of agritourism facilities in Italy. Statista (2021). Retrieved from https://www.statista.com/statistics/795702/number-of-agritourism-facilities-in-italy/ [22.06.2021]

Number of tourism day visits to rural (countryside or village locations) in Great Britain from 2011 to 2019. Statista (2021). Retrieved from https://www.statista.com/statistics/629211/number-of-day-visits-rural-location-greatbritain-uk/ 
Management Theory and Studies for Rural Business and Infrastructure Development eISSN 2345-0355. 2021. Vol. 43. No. 4: 555-561

Article DOI: https://doi.org/10.15544/mts.2021.50

Sigala M. (2020). "Tourism and COVID-19: Impacts and implications for advancing and resetting industry and research,” Journal of Business Research, Elsevier, vol. 117(C), 312-321 pp.

Žilinskas V., Maksimenko M. (2008). Kaimo tourizmo damios pletros perspectyvos. Management Theory and Studies for Rural Business and Infrastructure Development, 13, 214-223 pp. 